\title{
Kent İçi Trafikten Kaynaklanan Stratejik Gürültü Haritalarının Değerlendirilmesi
}

\author{
Şafak Hengirmen Tercan ${ }^{1, *}$, , Gökhan Yaman²® \\ ${ }^{1}$ Hasan Kalyoncu Üniversitesi, Inşaat Mühendisliği Bölümü, 27560, Gaziantep. \\ ${ }^{2}$ Gaziantep Büyükşehir Belediyesi, Çevre Koruma ve Kontrol Daire Başkanlığı, Gaziantep.
}

\section{Özet}

Kentlerde, trafik, sanayi ve eğlence gibi çeșitli faaliyetlerden oluşan çevresel gürültü önemli çevre sorunlarından birisi olmuştur. Gelişmiş ülkelerdeki sağlık sorunlarl siralamasında kara, hava ve demiryollarındaki trafikten kaynaklanan gürültü ikinci sırada yer almaktadır. Trafikten kaynaklanan gürültünün, insan sağlı̆̆ı üzerinde negatif etkileri bulunmaktadır. Yüksek nüfus yoğunluğu olan yaşam alanları trafikten kaynakl gürültü maruziyetlerinin oluştuğu bölgelerdir. Kentlerdeki gürültü alanlarını belirlemek ve yaşanabilir kentler oluşturmak için stratejik gürültü haritalarl hazırlanmaktadır. Böylece, çevresel gürültü ile ilgili sorunlar belirlenmekte ve gerekli kontrol tedbirleri alınabilmektedir. Bu çalışmada, Gaziantep'te nüfus yoğunluğu yüksek olan bölgelerde karayolu trafiğinden kaynaklanan stratejik gürültü haritaları trafik sayımları ve simülasyon programı ile oluşturulmuştur. Çalışma kapsamında 161 km'si ana karayolu olmak üzere toplam $193 \mathrm{~km}$ karayolu modellenmiş ve 33 yol kesitinde araç sayımı yapılmıştır. Elde edilen simülasyon verileri ile gündüz, akşam ve gece için stratejik gürültü haritaları hazırlanmıştır. Daha sonra, karayolu trafiğinden kaynaklanan gürültü sınır değerlerini așan bölgelerdeki nüfus oranları hesaplanmıștır. Buna göre, Gaziantep nüfusunun $\%$ 5,4'ü gündüzleri, \% 8,2 'si akşamlart ve \% 7,5'i geceleri belirlenen kritik seviyelerin üzerinde karayolu kaynakl gürültü seviyelerine maruz kalmaktadır. Hassas bölgeler olan 201 okul ve 95 hastane bu gürültü alanlarında bulunmakta ve karayolu kaynaklı gürültü seviyelerine maruz kalmaktadır.

\section{Anahtar Sözcükler}

Trafikten Kaynaklı Gürültü, Stratejik Gürültü Haritası, Gürültü Kirliliği

\section{Evaluation of Strategic Noise Maps Arising from Urban Traffic}

\begin{abstract}
$\underline{\text { Keywords }}$

Traffic Noise, Strategic Noise Map, Noise Pollution

\section{Giriş}

Environmental noise from traffic, industry and entertainment in cities has been one of the important environmental problems. In developed countries, noise from highways, airways and railways are the second major health problem. Traffic noise has negative effects on human health. The traffic noise exposes are occurring in the high populated living areas. Strategic noise maps are prepared to identify these noise areas in cities and to create liveable cities. Thus, problems related to environmental noise are identified and necessary control measures can be taken. In this study, strategic noise maps arising from the road traffic in Gaziantep with high population density were created with traffic counts and simulation program. Within the scope of the study, a total of $193 \mathrm{~km}$ of highways, $161 \mathrm{~km}$ of which are main roads, were modelled and vehicle counts were made on 33 road sections. Strategic noise maps were prepared for daytime, evening and night with the obtained simulation data. Then, the population ratios in the regions exceeding the noise limit values caused by road traffic were calculated. According to this; $5.4 \%$ of the population of Gaziantep is exposed to traffic noise levels above the critical levels determined during the day, $8.2 \%$ in the evening and $7.5 \%$ at night. Sensitive areas, 201 schools and 95 hospitals, are located in these noise areas and are exposed to traffic noise levels.

Kentlerde, trafik, sanayi ve eğlence gibi çeşitli faaliyetlerden oluşan çevresel gürültü önemli çevre sorunlarından birisi olmuştur. Dünya Sağlık Örgütü'nün (DSÖ) verilerine göre; sağlık sorunları sebepleri sıralamasında çevresel gürültü ikinci sırada gelmektedir. Aşırı gürültü insan sağlığına ciddi şekilde zarar vermekte ve insanların okulda, işte, evde ve boş zamanlarında günlük aktivitelerini olumsuz etkilemektedir. Gürültü, uyku bozukluğu, kardiyovasküler ve psiko-fizyolojik etkiler, performansı düşüklüğü ve rahatsızlık tepkileri ve sosyal davranışta değişiklikler oluşturmaktadır. Tek başına trafik gürültüsü, DSÖ Avrupa Bölgesinde neredeyse her üç kişiden birinin sağlığına zararlı olmakta ve her beş Avrupalıdan biri düzenli olarak geceleri sağlığa önemli ölçüde zarar verebilecek ses seviyelerine maruz kalmaktadır (WHO 2020). 
Dünya Sağlık Örgütü'nün “Avrupa İçin Gece Gürültüsü Kılavuzu”, gece gürültüsüne maruz kalmanın oluşturduğu sağlık sorunlarına dair kanıtlar sunmakta ve insan sağlığı üzerinde olumsuz etkilerin gözlendiği eşik değerleri belirtmektedir. Kılavuzda yıllık ortalama 40 desibeli (dB) aşmayan ortalama maruziyet önerilmiştir. Yıl boyunca ortalama 40 dB'in üzerinde gece gürültü seviyelerine maruz kalanlar, uyku bozukluğu ve uyanık kalma gibi etkilerle karşılaşmaktadır. Uzun süreli $55 \mathrm{~dB}$ ortalama maruziyetin üstünde oluşan gürültüler ise yüksek kan basıncını tetikleyebilmekte ve iskemik kalp hastalığına yol açabilmektedir. Avrupa Birliği'nde (AB) karayolu, demiryolu ve havayolu trafiğinden kaynaklanan gürültünün sağlığa etkileri konusunda yaptırılan bir araştırmaya göre her yıl yaklaşık 910 bin ek hipertansiyon vakası, en az 10 bin koroner kalp hastalığı ve inme ile ilgili erken ölüm vakası ve gürültü sebebiyle 43 bin hastaneye başvuru vakası oluşmaktadır. Bu çalışma, gürültüye maruz kalmayla ilgili kısmi verilere dayandığından, tüm AB'deki genel sağlık etkilerinin şu anda tahmin edilenden daha yüksek olması beklenebilir (EC 2020).

Amerikan Çevre Koruma Ajansı (EPA 1974) değerlerine göre 24 saat boyunca 70 dB ve üzeri gürültüye maruz kalanlarda kalıcı işitme kaybı olabilmektedir. EPA tarafından gürültüye hassas olan bölgeler olan konut, okul ve hastane bölgeleri için $45 \mathrm{~dB}$, dış mekânlar için ise $55 \mathrm{~dB}$ ses seviyesi üst limit olarak belirlenmiştir. Gürültünün insan sağlığ1 üzerine olan etkileri hakkında hazırlanan el kitabında ise işitme kaybı, fizyolojik tepkiler olarak; stres, kardiyovasküler etkiler, kalp krizi, yüksek tansiyon, inme veya felç, ülser, sindirim sistemi sorunları ve fetüs üzerindeki etkiler, psikolojik tepkiler olarak; anti sosyal davranış, yardım etme isteğinde azalma gibi etkiler görülebilmektedir (ERA 1981).

Trafikten kaynaklanan gürültünün insan sağlığı üzerindeki negatif etkileri ile ilgili birçok araştırma bulunmaktadır. Frankfurt'ta yapılan bir çalışmada sağlık sigortaları üzerinden alınan verilerle 40 yaşından büyük yaklaşık 578 bin kişi arasında 77 bin kişinin 24 saat sürekli $70 \mathrm{~dB}$ ve üzeri seviyede karayolu trafik gürültüsüne maruz kalması sebebiyle depresyona girdiği tespit edilmiştir (Seidler vd. 2017). Aynı şekilde hipertansiyon etkileri de gözlenmiştir (Zeeb vd. 2017). Yine Frankfurt'ta havayolu, karayolu ve demiryolu gürültüleri için yapılan bir çalışmada; kalp yetmezliği veya hipertansif kalp hastalığı ile istatistiksel olarak anlamlı bir doğrusal risk ilişkisi bulunmuştur. Buna göre havayolu gürültüsü 24 saatlik sürekli gürültü seviyesinde $10 \mathrm{~dB}$ artış başına $\% 1,6$ risk artışı; karayolu gürültüsü için $10 \mathrm{~dB}$ artış başına \% 2,4 risk artışı ve demiryolu gürültüsü için10 dB başına \% 3,1 risk artışı gözlenmiştir (Seidler vd. 2016). Diğer bir çalışmada farklı bir bakış açısıyla karayolu gürültüsünün emlak kiralarına olan etkileri incelenmiştir. Gürültü sürekli değişken olarak kullanıldığında $\mathrm{dB}$ başına \% 0,4 fiyat düşüşleri bulunmuştur. Gürültü kategorik bir değişken olarak kullanıldığında ise \% 9,6'ya varan bir düşüş modellenmiştir (KuehņeNe Moeckel 2020).

Avrupa Komisyonu, 2002 yilında Çevresel Gürültü Yönergesini (The Environmental Noise Directive, END) yayımlamıştır (EU 2002). Bu Yönergeye göre; Avrupa Birliği ülkelerinin kentsel planlamalarını gürültü kaynaklarını göz önünde bulundurarak yapması, gürültüye maruz kalma etkileri hakkında bilgilerin topluma ulaşmasının sağlanması ve ülkelerin gürültü politikalarının desteklenmesi amaçlanmıştır. Böylece, "Stratejik Gürültü Haritaları” şehirlerde çevresel gürültünün planlaması ve kontrolü için ana araç haline gelmiştî (Borelh vd. 2014). Bu aşamadan sonra, AB'ye üye ülkeler, gürültü denetimi ile ilgili devam etmekte olan çalışmalarına hız vermişler ve tüm yerleşimlerin gürültü haritalarının çıkartılması ve gürültü açısından mevcut durumun ortaya konmasına yönelik ortak yönergeler oluşturmuşlardır.

Ülkemizde, çevresel gürültü ile ilgili AB Yönergesinin (2002/49/EC) uyumlaştırılması ve uygulanması amacıyla AB ile ortak projeler yapılmıştır. Türkiye için gürültünün kontrolü ve azaltılmasına yönelik hedef ve ilkeler belirlenmiş ve “2009-2020 Çevresel Gürültü Eylem Planı” hazırlanmıştır (ÇŞB 2018). Konu ile ilgili kurum ve kuruluşların görevlerinin belirlenmesi ve işbirliği içinde çalışmaların yapılması amacıyla belirlenen çevresel gürültü standartlarını sağlayacak şekilde çalışmaların yapılmasına yönelik Çevresel Gürültünün Değerlendirilmesi ve Yönetimi Yönetmeliği (ÇGDYY) yürürlüğe girmiştir (URL-1 2010). Yönetmelik, kişilerin beden ve ruh sağlığını, huzur ve sükûnunu gürültü ile bozmayacak bir çevrenin geliştirilmesi için, çevresel gürültüye maruz kalmanın etkileriyle mücadele etmeye yönelik esas ve kriterlerin belirlenmesi ve bu kriterlerin gürültü kaynakları bazında uygulanması için çeşitli kaynaklardan yayılan gürültü emisyonuna sınırlamalar getirmiştir. Ayrıca, yerleşim yerleri, karayolları, demiryolları ve hava alanları için gürültü düzeylerini ve bu düzeylere maruz kalan konut, okul, hastane ve etkilenen kişi sayısını gösteren gürültü haritalarının hazırlanmasını belirtmektedir. Bu harita sonuçları esas alınarak, özellikle çevresel gürültüye maruz kalma seviyelerinin insan sağlığı üzerinde zararlı etkilere yol açtığı yerler ile çevresel gürültü seviyesinin aşılmamasının gerekli olduğu yerlerde, gürültünün kontrol altına alınmasına yönelik eylem planları hazırlanarak uygulamaya konulması öngörülmektedir. Stratejik gürültü haritalama esaslarına göre 250 bin'den fazla yerleşik nüfusu olan ve nüfus yoğunluğu kentleşmiş alanda $1000 \mathrm{kişi} / \mathrm{km}^{2}$ 'den fazla olan yerleşim alanları, stratejik gürültü haritalarının hazırlanması gereken öncelikli alanlar olarak tanımlanmıştır (URL-1 2010). Ayrıca Çevre Kanunu ve Mekânsal Planlar Yapım Yönetmeliğinde Madde 21(5)'de de İmar planlarında, planlama alanının niteliğine göre mevzuatta öngörülen sağlık koruma bantları, güvenlik bölgesi ve benzeri koruma kuşakları gösterilir. İmar planları, varsa stratejik gürültü haritaları ve eylem planları dikkate alınarak hazırlanır ve planlarda bu konuda gerekli tedbirler alınır" denilmektedir (URL-2 2014).

\subsection{Türkiye'de yapılan çalışmalar}

Türkiye'de gürültü ile ilgili yapılan birçok çalışma bulunmaktadır. Bu çalışmaların büyük kısmı büyükşehir olmayan il ve ilçe merkezlerinde yer almıştır (Sillelioğlu 2004; Özdemir ve Kalıpcı 2011; Kalıpcı ve Dursun 2009). 
Afyonkarahisar için yapılan çalışmada elde edilen değerlerin \%58,5'i $80 \mathrm{~dB}(\mathrm{~A})$ 'in, \%6,85'i $90 \mathrm{~dB}(\mathrm{~A})$ 'in üstündedir (Erdoğan vd. 2007). Giresun'da 99 noktada yapılan gürültü ölçümleri ve coğrafi bilgi sistemi ile haritalama çalışmasında, limanın şehir içinde, kafe ve düğün salonlarının konut bölgelerinde bulunmasından dolayı kentteki sanayi, eğlence ve trafik gürültüsünün birbirine karıştığı ve yoğunluğu artırdığı görülmüştür. 3 caddede $68 \mathrm{~dB}(\mathrm{~A})$ değeri aşılmıştır (Kalıpc1 ve Dursun 2009). Sarayönü ilçesinde 44 noktada yapılan çalışmada gürültü ölçüm seviyelerinin sabah 45-103 dB(A), öğlen 44-90 dB(A) ve akşam 39-82 dB(A) aralığında olduğu belirlenmiştir (Öden ve Bilgin 2019). Avanos'ta 24 noktada yapılan çalışmada eşdeğer gürültü ölçüm seviyelerinin gündüz 79-85 dB(A) aralığında olduğu ve ilçe giriş-çıkış karayollarındaki maksimum gürültü seviyesinin $\mathrm{L}_{\max } 109 \mathrm{~dB}(\mathrm{~A})$, minimum $\mathrm{L}_{\min } 82 \mathrm{~dB}(\mathrm{~A})$ olduğu belirlenmiştir (Kalıpc1 2017).

Büyükşehir belediyesi sınırlarında olan ilçe alanlarını kapsayan yapılan çalışmalarda, örneğin İzmit kent merkezinde gündüz 1 cadde, 6 okul, 4 park alanı ve 2 hastane alanındaki trafikten kaynaklı gürültü $70 \mathrm{~dB}(\mathrm{~A})$ sınır değerin üzerinde olarak tespit edilmiştir. Aynı şekilde akşam için; 2 cadde, 1 üniversite, 6 park ve 2 hastane $65 \mathrm{~dB}(\mathrm{~A})$ sınır değerin üzerinde olarak tespit edilmiştir. Son olarak gece için; 1 cadde, 6 park ve 2 hastane $60 \mathrm{~dB}(\mathrm{~A})$ sınır değerin üzerinde olarak tespit edilmiştir (Bayraktar 2006). Benzer şekilde Samsun'da en büyük nüfuslu 2. İlçe olan Atakum ilçesinde yapılan çalışmada, hafif raylı sistem ve aynı güzergâhta bulunan karayolundaki trafikten kaynaklanan gürültü seviyeleri ölçülmüştür. Lgündüz 1zgaralı gürültü haritası incelendiğinde, güzergâhta bulunan binaların konumu, açıları ve çizgisel gürültü kaynaklarına olan uzaklıklarına göre 65-70 dB(A) ve 70-75 dB(A) aralığında ulaşım gürültüsüne maruz kaldıkları görülmektedir. Lakşam 1zgaralı gürültü haritası verileri incelendiğinde, binaların maruz kaldığı en yüksek gürültü düzeyinin $65-70 \mathrm{~dB}(\mathrm{~A})$ olduğu tespit edilmiştir. Lgece 1zgaralı gürültü haritası verilerine 55-60 dB(A) ve 60-65 dB(A) aralığında ulaşım gürültüsüne maruz kaldıkları anlaşılmaktadır. L(gag) gürültü haritasına bakıldığında çalışma aksından cephe alan binaların konumu, açıları ve çizgisel gürültü kaynaklarına olan uzaklıklarına göre ağırlıklı olarak 70-75 dB(A) aralığında ulaşım gürültüsüne maruz kaldıkları görülmektedir (Öner ve Sesli 2018).

Konya'da trafikten kaynaklı gürültü için farklı çalışmalar da mevcuttur (Özden ir vd. 2012; Kalıpc1 ve Aslan 2007). Büyükşehir belediyesinde bulunan tüm merkez ilçeleri kapsayan çalışmalar için örnek Konya'da yapılmıştır. Çalışmadaki sonuçlara göre gündüz vakti için nüfusun yaklaşık \%25-30'u yani 80 bin konut 300 bin konut sakininin $60 \mathrm{~dB}(\mathrm{~A})$ seviyesinde trafikten kaynaklı gürültüye maruz kaldığını göstermektedir. L gece değerleri kapsamında değerlendirildiğinde; trafikten kaynaklı $55 \mathrm{~dB}(\mathrm{~A})$ değerini aşan gürültüye maruz nüfusun yaklaşık \%10-15 olduğu ve 60 bin konut, 200 bin kişiyi kapsadığını göstermektedir (Dalkılıç ve Dursun 2019).

Bu çalışmada, Gaziantep’te, büyükşehir kapsamındaki tüm merkez ilçeleri kapsayacak bir alanda, nüfus yoğunluğu yüksek olan bölgelerde karayolu trafiğinden kaynaklanan stratejik gürültü haritaları trafik sayımları ve simülasyon programı ile oluşturulmuştur. Elde edilen simülasyon verileri ile gündüz, akşam ve gece için stratejik gürültü haritaları hazırlanmıştır. Daha sonra, karayolu trafiğinden kaynaklanan gürültü sınır değerlerini aşan bölgelerdeki nüfus oranları hesaplanmiştır.

\section{Materyal ve Yöntem}

Son yıllarda, çevresel gürültü haritalarının hazırlanması için birçok farklı simülasyon modelleri kullanılmıștır (Borelli vd. 2014; Lee vd. 2014; Vogiatzis ve Remy 2014; Gulliver vd. 2015). Bu modelleme araçları, planlama aşamasında ölçüm yapmanın mümkün olmadığı durumlarda çok kullanışlı olmaktadır. CadnA ve SoundPLAN gibi programlar çevresel gürültü haritalamasında en yaygın kullanılanlar arasında sayılabilir (Khan vd. 2018). Bu yazılımlar yetkin, güvenilir ve trafik gürültüsünü modellemek için genellikle doğru araçlar olarak kabul edilmektedir (Karantonis vd. 2019). SoundPLAN kullanıcı kolaylığı sağlayan, yerel verilerle uyumlu ve önceki çalışmalarda başarılı sonuçlar elde etmiş bir yazılım olarak bilinmektedir (Bodin vd. 2009; Sorensen vd. 2012; 2013; 2014; 2015). Bu sebeple, bu çalışmada, motorlu taşıt trafiğinden kaynaklanan çevresel gürültünün modellenmesi için SoundPLAN kullanılmıştır. Proje kapsamında NMPB Routes 96 isimli Fransız ulusal hesaplama yöntemi de kullanılarak karayolu trafik gürültüsü belirlenmiştir (Besnard d. 2001).

Mevcut veya tahmin edilen gürültü düzeylerini ve gürültü kaynağını belirlemek için çevresel gürültü haritaları kullanılmaktadır. Çevresel gürültü haritaları ile gürültü limitlerinin aşıldığı alanlar tespit edilmektedir. Böylece, gürültüden etkilenen konut, okul, hastane gibi hassas yapılar ve bölgedeki nüfus belirlenmektedir. Gürültü haritaları coğrafi veri tabanları üzerine eklenen bilgi katmanları olarak tanımlanır. Bir bölgenin sınırları belirlenerek yeterli sayıda alıcı nokta yerleştirilmekte ve bu noktalardaki gürültü düzeyleri tek tek hesaplanarak gürültü konturları oluşturulmaktadır. Coğrafi haritalar ve yerleşim planları kullanılarak alıcı noktalar ve aralarındaki mesafeler arazi üzerinden tespit edilmektedir. Bu nedenle gürültü haritalarını hazırlama çalışmaları sırasındaki en önemli adımlardan biri fiziksel çevre verilerinin saptanması olarak belirtilmektedir. Bu veriler, yapıların konumu ve yükseklikleri, kat adetleri, zemin tipleri, topoğrafik durum ile doğal ve yapay engellerden oluşmaktadır.

Gürültü haritası sonuçlarında elde edilen çevresel gürültü üzerine, çalışmanın yapılacağı alandaki binaların yoğunluğu ve şekli, açık alanların varlığı ve fiziksel şekli vb. arazi özelliklerinin önemli etkileri bulunmaktadır. Gürültü haritası hazırlanması için çalışılan alanda bulunan tüm arazi kullanım bilgilerinin, oluşturulan coğrafi veri tabanı içerisinde değerlendirilmesi gerekmektedir (Italio vd. 2011). 
Çalışmadaki arazi kullanımına ait sayısal haritalar, Çevre ve Şehircilik Bakanlığı'ndan elde edilen “Coordination of Information on the Environment (CORINE)" Arazi Sınıflandırma Sistemi kullanılarak hazırlanmıştır. CORINE Sınıflandırma Sistemi 1990 yılından beri tüm AB Üye ülkelerinde kullanılan ortak sınıflandırma sistemidir. Türkiye'de ise 1998 yılında Çevre ve Şehircilik Bakanlığı tarafından uygulanmaya başlanmıştır. 2006 yılı uydu görüntüleri kullanılarak yapılan ilk çalışma 2008 yılı ortalarında tamamlanmıştır (Çivi vd. 2009).

CORINE Sistemi dört temel amaca hizmet etmektedir:

1. Avrupa Birliği'nin bütün üye devletleri için belirlenmiş öncelikli konulara göre çevrenin durumu ile ilgili bilgilerin toplanmasi,

2. Üye devletler içinde ya da uluslararası düzeyde, verilerin toplanması ve bilgilerin uyumlu hale getirilmesi,

3. Bilgilerin tutarlılığının ve verilerin uyumluluğunun sağlanması,

4. Avrupa Çevre Ajansı kriterlerine göre "Arazi Kullanım” haritalarının oluşturulması.

Ayrıca CORINE Sistemi ile farklı düzeylerde yapılan çok sayıdaki çalışma ile toplanan çevresel bilgilerin yıllar itibariyle değişimininin izlenmesi sağlanmaktadır.

\subsection{Model oluşturulması}

Çalışma alanı, sayısal haritalar, koordinatlar, arazi kotları ve bina bilgi sistemi gibi katmanlarla modellenmiştir. Bina bilgi sistemi binaların kullanım amacı, kat sayısı, binadaki daire sayısı vb. bilgileri kapsamaktadır. Arazi modellemesi yapıldıktan sonra bina nüfus bilgilerini kapsayan bir veri tabanı oluşturulmuştur. Hesaplamanın üçüncü adımında, proje çalışma alanı içerisinde yer alan gürültü kaynağı olan karayolu trafiği modele işlenmiştir.

Ana karayolu yılda üç milyondan fazla aracın geçtiği bölgesel, ulusal veya uluslararası karayollarını kapsamaktadır. Tanımlanan ana karayollarının belirlenmesi amacıyla otoyollar ve devlet yollarına ait bilgiler Karayolları Genel Müdürlüğü'nden temin edilmiştir. Kent içinde belirlenen yoğun caddeler ve ana arterler için Gaziantep Büyükşehir Belediyesi tarafından 2014 yılında yapılan trafik sayımları göz önüne alınıştır. Ayrıca, 2006 yılında hazırlanan hâlihazır haritalar ve imar planları kullanılmıştır.

Motorlu taşıtlardan kaynaklanan gürültüler incelenirken öncelikle taşıtların sınıflandırılması gerekmektedir. Taşıtlar, gereksinime bağlı olarak tekerlek sayılarına, akslarına, kullanım amaçlarına ve tiplerine göre değişik biçimlerde sınıflandırılır. Gürültü açısından sınıflandırma ise, gürültü emisyonlarına bağlı olarak, ağır ve hafif taşıtlar biçimindedir. Üç tondan ağır olan çeşitli büyüklükteki kamyonlar, otobüsler ağır taşıt olarak sınıflandırılırken, otomobil ve motosiklet ise hafif taşıt olarak nitelendirilebilir (TS 6407 2013; TRB 2010). Gerçekleştirilen araştırma sonuçlarına göre gürültü düzeyleri; artan taşıt ağırlığı, motorun bakımsız ve eski olması, artan hız ve ivmeye bağlı olarak artmaktadır (Nelson and Piner 1977; Nelson 1987). Genellikle yüksek hızlarda lastik/yol yüzeyi sürtünme gürültüsü, orta hızlarda aerodinamik gürültü ve düşük hızlarda motor gürültüsü önemli olmaktadır.

Karayolu gürültüsünün spektral özellikleri incelendiğinde; gürültü seviyelerinin düşük frekanslarda daha yüksek olduğu saptanmıştır. Ağır taşıtların referans gürültüleri; yol kenarından 7,5 m'de düşük frekanslarda 90 dB seviyesine kadar ulaşırken, yüksek frekanslarda 45 dB'e kadar düşmektedir. "A" ağırlıklı toplam gürültü düzeyinde ise ağır taşıtlar yaklaşık $80 \mathrm{~dB}(\mathrm{~A})$ ve hafif taşıtlar $70 \mathrm{~dB}(\mathrm{~A})$ civarında gürültü emisyonlarına sahiptirler (Kurra 2009).

Tekil ve durağan durumda iken noktasal kaynak olarak nitelendirilen motorlu taşıtlar, bir doğrultu boyunca sıralanmaları sonucunda çizgisel kaynak olarak incelenmektedir. Ayrıca ulaşım gürültüsü bir alan içerisinde yaygın gürültü biçiminde düşünülerek düzlemsel kaynak olarak da ele alınır. Karayolu gürültüsüne etki eden önemli etmenlerden birisi de trafik akışıdır. Ulaşım akışının niteliği (kesikli veya kesiksiz akış), durmalar, ivmelenmeler kavşak, trafik lambaları ve ulaşım sıkışıklığı ile) ve vites değişimlerinin çevresel gürültü düzeylerine önemli etkileri mevcuttur. Karayolundan kaynaklanan gürültüde diğer önemli bir etken de ulaşımın hacmi (taşıt/birim zaman) veya gece-gündüz ağırlığı uygulanarak bulunan "efektif taşıt sayısı" olarak belirtilebilir (Johnson ve Saunders 1968).

Bunlarla birlikte yolların kaplamalarının da (asfalt, beton ve parke gibi) gürültü düzeyleri üzerindeki etkileri araştırılmış ve özellikle soğuk iklim bölgelerinde kaymaya karşı uygulanan yivli ya da oluklu beton yüzeylerin, sürtünmeden dolayı gürültü düzeylerini arttırdı̆̆ı ifade edilmiştir (Kurra 2009). Yol eğiminin artması, yollarda bulunan kurba ve kavşaklar, yolların çevreye göre yükseltilmiş veya alçaltılmış olması özellikle gürültünün yayılma alanını etkiler ve topoğrafik etkiler ile yapısal etkilerin doğru saptanmasını gerektirir. Yol genişliği ve şerit sayısı ise gürültü hesaplamalarında, trafik hacmi, kaynak uzaklığı gibi diğer değişkenleri de etkiler. Özetle, trafik 1şıkları, eğimler ve kavşaklar ya da topografya, meteorolojik koşullar ve düşük fon gürültüleri gibi trafik hareketleriyle taşıtın hızında ve gücünde değişikliklerin gerektirdiği özel bölgelerde ve durumlarda gürültü düzeyleri yükselebilir. Karayolu kaplama malzeme tipleri "düz asfalt, gözenekli yüzey, beton yol veya stabilize yol" olarak tanımlanabilmektedir.

Karayolu gürültüsüne etki eden bu faktörlerin dişında, yolun tek veya çift yönlü olması, şerit sayısı, yol kaplama malzemelerinin dokusu, boşluk oranı ve yoğunluğu da önemlidir. Yoldaki iniş eğimi, gürültü seviyelerinde azalmaya sebep olurken, yukarı eğim olduğunda ise motorun daha fazla zorlanması ve parçaların üzerine daha fazla yük binmesi nedeniyle gürültü emisyon miktarında artışlar gözlenmektedir. 


\section{2. Çalışma Alanı}

Çalışmadaki stratejik gürültü haritası alanı, Gaziantep Büyükşehir Belediyesi merkez ilçeleri olan Şahinbey ve Şehitkâmil ilçeleri sınırları içerisindeki şehirleşmiş alanlar olarak belirlenmiştir. Şahinbey'de 187, Şehitkâmil'de 144 mahalle çalışma alanına dâhil edilmiştir. 2014 yılı verilerine göre gürültüden etkilenen alan içerisindeki toplam nüfus 1.556 .381 kişidir. Nüfusu 100 binden fazla olan, şehirleşmiş alan olarak kabul edilen ve nüfus yoğunluğunun kilometrekare başına bin kişiden fazla olduğu alanlar, stratejik gürültü haritalama esaslarına göre haritası hazırlanacak yerleşim alanı olarak belirlenmiştir. Şehirleşmiş bölgeler çalışma alanına dâhil edilmiş boş araziler ise kapsam dişı bırakılmıştır. Gürültü haritalarının oluşturulmasında proje çalışma alanı için arazi kullanım bilgileri değerlendirilmiştir. Bu iki ilçede şehir yapısı yaklaşık çalışma alanlarının \% 2'sini kapsamaktadır. Şahinbey ve Şehitkâmil ilçeleri arazi kullanımı bilgileri sırasıyla, Tablo 1'de verilmektedir. Şehitkâmil ve Şahinbey ilçelerinde çalışma alanı ve bulunan gürültü kaynaklarının konumları Şekil 1'de gösterilmiştir.

Tablo 1: Gaziantep Şahinbey ve Şehitkâmil ilçeleri arazi kullanımı

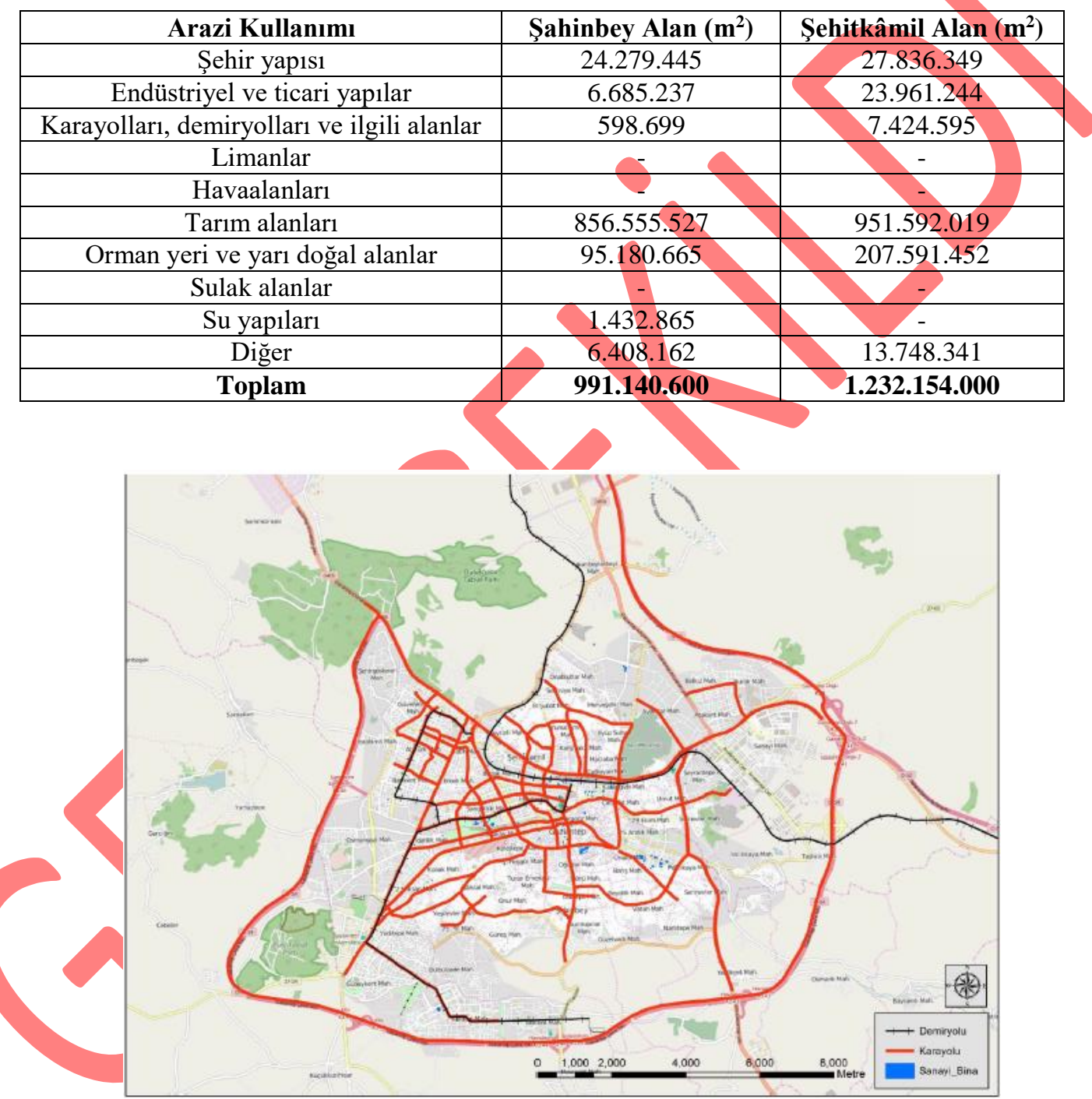

Şekil 1: Şahinbey ve Şehitkâmil ilçelerindeki trafik gürültü kaynaklarının (demiryolu ve karayolu) konumları

\subsection{Stratejik Gürültü Haritaları için Trafik Sayımları}

Çalışma kapsamında 161 km’si ana karayolu olmak üzere toplam 193 km karayolu modellenmiștir. Yılda üç milyondan fazla aracın geçtiği ana karayolları ile kent içi trafiğin yoğun olduğu toplamda 33 yol kesitinde araç sayımları gerçekleştirilmiştir. Araçlar gürültü emisyonlarına bağlı olarak hafif ve ağır olarak kategorize edilmiştir. Üç tondan ağır araçlar ağır taşıt kategorisine girmektedir. Karayolu gürültü seviyeleri taşıt ağırlığı, motor bakımı ve yaşı, hız ve ivme, trafik akışı, kavşaklar, trafik lambaları, ulaşım sıkışıklığı, yol kaplamaları, yol eğimi, topoğrafik etkiler, yol genişliği gibi değişkinlere bağlı olarak hesaplanmıştır. 
Belirlenen yol kesitlerinde günün üç zaman dilimini (gündüz, akşam ve gece) temsil eden zirve saatlerde 1 saatlik taşıt sayımları ağır ve hafif araç olarak sınıflandırılarak yapılmıştır. Hafta sonu trafik yoğunluğu hafta içine oranla farklılık gösteren yollar içinde ayrıca günün üç zaman dilimini temsil eden en yoğun saatlerde1 saatlik taşıt sayımları gerçekleştirilmiştir. Saha çalışmaları sonucunda elde edinilen sayım verileri tüm zaman dilimleri için Tablo 2 'de verilmektedir.

Tablo 2: Proje çalışma alanı içerisinde yer alan karayollarına ait taşıt sayımları (taşıt/saat)

\begin{tabular}{|c|c|c|c|c|c|c|c|}
\hline \multirow[t]{2}{*}{ Cadde/Sokak } & \multirow{2}{*}{$\begin{array}{l}\text { Yol } \\
\text { kaplaması }\end{array}$} & \multicolumn{2}{|c|}{ Gündüz (07:00-19:00) } & \multicolumn{2}{|c|}{ Akşam (19:00-23:00) } & \multicolumn{2}{|c|}{ Gece (23:00-07:00) } \\
\hline & & Ăğır taşıt & Hafif taşıt & Ağır taşıt & Hafif taşıt & Ăğır taşıt & Hafif taşıt \\
\hline $\begin{array}{l}\text { Hoca Ahmet } \\
\text { Yesevi Cad. }\end{array}$ & Düz Asfalt & 137 & 333 & 12 & 82 & 3 & 37 \\
\hline Duisburg Bulv. & Düz Asfalt & 162 & 586 & 86 & 467 & 29 & 206 \\
\hline Mustafa Taşar Cad. & Düz Asfalt & 128 & 428 & 119 & 245 & 9 & 18 \\
\hline $\begin{array}{l}\text { Hasan Celal Güzel } \\
\text { Cad. }\end{array}$ & Düz Asfalt & 141 & 441 & 138 & 461 & & 17 \\
\hline $\begin{array}{c}\text { Vehbi Dinçerler } \\
\text { Cad. }\end{array}$ & Düz Asfalt & 88 & 341 & 32 & & & 164 \\
\hline $\begin{array}{c}\text { Gazi Ali Düşün } \\
\text { Cad. }\end{array}$ & Düz Asfalt & 114 & 516 & 346 & 347 & 7 & 45 \\
\hline $\begin{array}{c}\text { Muhsin Yazıcıoğlu } \\
\text { Cad. }\end{array}$ & Düz Asfalt & 212 & 426 & & 567 & & 72 \\
\hline Kemal Köker Cad. & Düz Asfalt & 94 & 256 & 63 & 203 & 9 & 22 \\
\hline Atatürk Bul. & Düz Asfalt & 276 & 933 & 172 & 505 & 62 & 258 \\
\hline İnönü Cad. & Düz Asfalt & 649 & 1.073 & 554 & 1.074 & 67 & 180 \\
\hline Tüfekçi Yusuf Cad. & Düz Asfalt & 866 & 1.192 & 449 & 851 & 229 & 530 \\
\hline Maaş Kuyu Cad. & Düz Asfalt & 282 & 467 & 359 & 538 & 28 & 60 \\
\hline Hafiz Tevfik Cad. & Düz Asfalt & 500 & 636 & 213 & 365 & 61 & 111 \\
\hline Kâtip Hoca Cad. & Düz Asfalt & 90 & 264 & 55 & 161 & 17 & 37 \\
\hline Şöför Ali Cad. & Düz Asfalt & 28 & 114 & 15 & 80 & 5 & 24 \\
\hline Tekel Cad. & Düz Asfalt & 71 & 318 & 46 & 234 & 13 & 36 \\
\hline Lefkoşe Cad. & Düz Asfalt & 427 & 382 & 211 & 360 & 84 & 115 \\
\hline Hasip Düri Cad. & Düz Asfalt & 246 & 393 & 174 & 212 & 22 & 37 \\
\hline $\begin{array}{l}\text { Yavuz Sultan Selim } \\
\text { Cad. }\end{array}$ & Düz Asfalt & 328 & 528 & 238 & 714 & 154 & 508 \\
\hline $\begin{array}{l}\text { Mehmet Oğuz } \\
\text { Göğüş Cad. }\end{array}$ & Düz Asfalt & 279 & & 254 & 535 & 46 & 245 \\
\hline 77 Cadde & Düz Asfalt & 410 & 562 & 195 & 361 & 16 & 26 \\
\hline Şanlıdere Cad. & Düz Asfalt & 413 & 387 & 317 & 350 & 36 & 78 \\
\hline $\begin{array}{l}\text { Âş1k Mahsuni Şerif } \\
\text { Cad. }\end{array}$ & Düz Asfalt & 278 & 446 & 199 & 319 & 112 & 92 \\
\hline Özdemir Cad. & Düz Asfalt & 495 & 783 & 244 & 515 & 40 & 50 \\
\hline 140 Cad. & Düz Asfalt & 264 & 489 & 246 & 438 & 85 & 153 \\
\hline 216 Cad. & Düz Asfalt & 585 & 1.067 & 417 & 939 & 20 & 92 \\
\hline $27041 \mathrm{Cad}$. & Düz Asfalt & 81 & 335 & 41 & 289 & 10 & 50 \\
\hline Karkamış Cad. & Düz Asfalt & 85 & 201 & 42 & 152 & 8 & 26 \\
\hline $\begin{array}{l}\text { Fatih Sultan } \\
\text { Mehmet Bul. }\end{array}$ & & 100 & 278 & 60 & 254 & 11 & 41 \\
\hline Cumhuriyet Cad. & Düz Asfalt & 138 & 374 & 63 & 288 & 17 & 49 \\
\hline D850-14 1.K1s1m & Düz Asfalt & 457 & 1.853 & 216 & 1.531 & 108 & 483 \\
\hline D400-23 3. K1sim & Düz Asfalt & 113 & 364 & 66 & 252 & 42 & 70 \\
\hline O54 Otoyolu & Düz Asfalt & 228 & 672 & 88 & 463 & 53 & 123 \\
\hline
\end{tabular}

Sayımları yapılan yol kesitleri ve Karayolları Genel Müdürlüğüne bağlı karayolları günlük araç yoğunlukları belirlenmiş olan 9 ana arterde (Sani Konukoğlu Bulvarı, Abdulkadir Aksu Bulvarı, Ali Şir Nevai Caddesi, Bahriye Üçok Bulvarı, İstasyon Caddesi, Gazi Mustafa Kemal Bulvarı, Ali Fuat Cebesoy Bulvarı, Ali Nadi Ünler Bulvarı ve Mareşal Fevzi Çakmak Bulvarı) modelleme çalışmalarına dahil edilmiştir. 


\subsection{Model Sonuçlarının Doğrulanması}

Avrupa Komisyonu çalışma grubu tarafından 2007 yılında yayımlanan kılavuza göre, $300 \mathrm{~m}$ doğrulama mesafesi içerisinde model ile ölçüm değerleri arasındaki farkın $1 \mathrm{~dB}, 600 \mathrm{~m}$ uzakta $3 \mathrm{~dB}$ ve $2-3 \mathrm{~km}$ uzaklıklarda ise $10 \mathrm{~dB}$ olabileceği belirtilmektedir (EC 2007). Yine END'de (EU 2002) belirtilen gürültünün değerlendirilmesinde kentsel alanlarda alıcı noktalar için hesaplanan gürültü değerlerinin standart sapmasının yaklaşık $5 \mathrm{~dB}(\mathrm{~A})$ olabileceği belirtilmektedir (Vos vd. 2005). Birleşik Devletler Otoyol İşletmeleri Ulaştırma Departmanı tarafindan 2010 y1lında yayınlanan rehbere göre karayolu gürültüsü modelleme sonuçlarının $\pm 3 \mathrm{~dB}(\mathrm{~A})$ değerinde doğrulukta kabul edilebileceği öngörülmektedir. Ölçüm sonuçları ile model çıktıları arasındaki farklılıkların nedenleri olarak; kent ölçeğinde bir çok farklı kaynağın alıcı noktadaki ölçüm sonucuna etkisi, hesaplama yazılımı ve yöntemden kaynaklı belirsizlik, hesaplama alanındaki bina, yer geometrisi ve emisyon girdileri sıralanabilir (USDT 2010).

Proje çalışma alanındaki belirlenen alıcı noktalar farklı mesafelerdeki karayolu, demiryolu sanayi ve eğlence tesislerinden yayılan gürültü emisyonlarının etkisi altında kalmaktadır. Kaynak bazında mesafeye bağlı hesaplanan model sonuçlarının doğrulamasını bağımsız olarak yapmak mümkün değildir. Dolayısıyla alıcı noktalar için hesaplanan model sonuçları tüm kaynakların etkisi dikkate alınarak değerlendirilmiş̧ir. Tüm zaman dilimleri için hesaplanan model sonuçları ölçümler ile karşılaştırıldığında alıcı noktaların yaklaşık \% 75'inde farkın $3 \mathrm{~dB}(\mathrm{~A})$ seviyesinin altında olduğu belirlenmiştir. Sonuç olarak, model çıktılarının uluslararası kabul görmüş kaynaklardaki belirtilen kriterlere göre oldukça iyi ve güvenilir aralıklarda olduğuna karar verilmiştir (TÜBİTAK-MAM 2016).

\section{Bulgular ve Tartışma}

Çalışma alanı içerisinde gürültüye maruz kalan konut sayısı, okul sayısı, hastane sayısı ve yaşayan kişi sayısı için SoundPLAN programı kullanılarak etkilenme analizi yapılmıştır. Etkilenme analizi için, en fazla gürültü alan cephede ve zeminden $4 \mathrm{~m}$. yüksekteki gürültü seviyesi farklı değer aralıklarına göre hesaplanmıştır. Bu gürültü seviyeleri Tablo 3'de gösterilmiştir. Bunlara ilave olarak değer aralıklarına göre gürültüye maruz kalan tahminí konut sakini sayılarının yüzdelik dilimlerinin de belirlenmesi gerekmektedir. Binaları etkileyen gürültü, bina cephelerinde zeminden $4 \mathrm{~m}$ yükseklikte ve cephenin $2 \mathrm{~m}$ önünde ölçüldüğünde eğer ölçülen en yüksek değerden $20 \mathrm{~dB}(\mathrm{~A})$ daha düşük ise bu cephe sakin cephe olarak tanımlanmaktadır. Haritalar hazırlanırken bu gürültü seviyeleri Tablo 3'deki farklı renklerde gösterilmiştir.

Trafik yoğunlukları ve akışlarının çevrelerine etkileri gündüz, akşam ve gece zaman dilimlerine göre değişmektedir. $\mathrm{Bu}$ sebeple, çalışma alanındaki karayollarının çevresindeki maruziyet hesaplamaları gün içerisindeki farklı zamanlarda ayrı ayrı yapılmıştır.

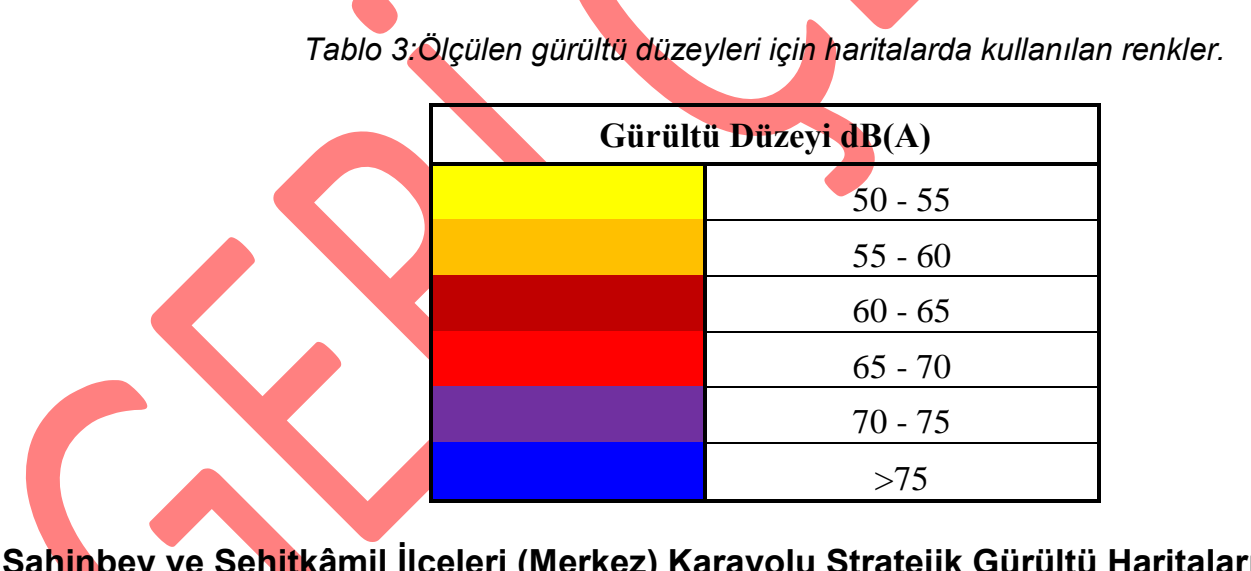

\section{1. Şahinbey ve Şehitkâmil İlçeleri (Merkez) Karayolu Stratejik Gürültü Haritaları}

Ortalama gürültü değeri $\left(L_{g a g}\right)$ ve gündüz ölçülen gürültü değeri $\left(L_{g u ̈ n d u ̈ z ~}\right)$ gürülttü düzeylerine göre hesaplanan etkilenme analizi sonuçları Tablo 4 'te verilmektedir. $5 \mathrm{~dB}(\mathrm{~A})$ kontur aralıkları ile hazırlanmış $\mathrm{L}_{\text {gag }}$ ve $\mathrm{L}_{\text {gündüz }}$ Karayolu Stratejik Gürültü Haritası Şekil 2'de verilmektedir. Renkler sarıdan maviye doğru giderken gürültü seviyesi Tablo3'de gösterildiği gibi artmaktadir. 
Tablo 4: Şahinbey ve Şehitkâmil ilçeleri (merkez) karayolu gürültüsü etkilenme analizi hesaplama sonuçları, Lgag ve Lgündüz

\begin{tabular}{|l|c|c|c|c|c|c|c|c|c|c|}
\hline & \multicolumn{5}{|c|}{ Lgag } & \multicolumn{5}{|c|}{ Lgundüz } \\
\hline $\begin{array}{l}\text { Gürülttï } \\
\text { Düzeyi } \\
(\mathbf{d B}(\mathbf{A}))\end{array}$ & $\begin{array}{c}\text { Alan } \\
\left(\mathbf{k m}^{2}\right)\end{array}$ & Konut & $\begin{array}{l}\text { Konut } \\
\text { Sakini }\end{array}$ & Okul & Hastane & $\begin{array}{c}\text { Alan } \\
\left(\mathbf{k m}^{2}\right)\end{array}$ & Konut & $\begin{array}{l}\text { Konut } \\
\text { Sakini }\end{array}$ & Okul & Hastane \\
\hline $\mathbf{5 0 - 5 4}$ & 35,4 & 65.600 & 228.700 & 121 & 17 & 31 & 50.300 & 188.500 & 94 & 18 \\
\hline $\mathbf{5 5 - 5 9}$ & 28,9 & 36.100 & 147.100 & 91 & 26 & 23,5 & 27.000 & 116.100 & 76 & 20 \\
\hline $\mathbf{6 0 - 6 4}$ & 19,1 & 20.800 & 93.400 & 61 & 13 & 13,3 & 16.000 & 74.700 & 49 & 19 \\
\hline $\mathbf{6 5 - 6 9}$ & 10,2 & 12.400 & 64.400 & 42 & 24 & 7,2 & 10.500 & 54.300 & 37 & 14 \\
\hline $\mathbf{7 0 - 7 4}$ & 5,8 & 9.100 & 43.800 & 39 & 13 & 4,8 & 7.900 & 38.000 & 29 & 15 \\
\hline$>\mathbf{7 5}$ & 6,4 & 9.200 & 38.000 & 11 & 10 & 4,8 & 7.000 & 28.000 & 6 & 5 \\
\hline
\end{tabular}

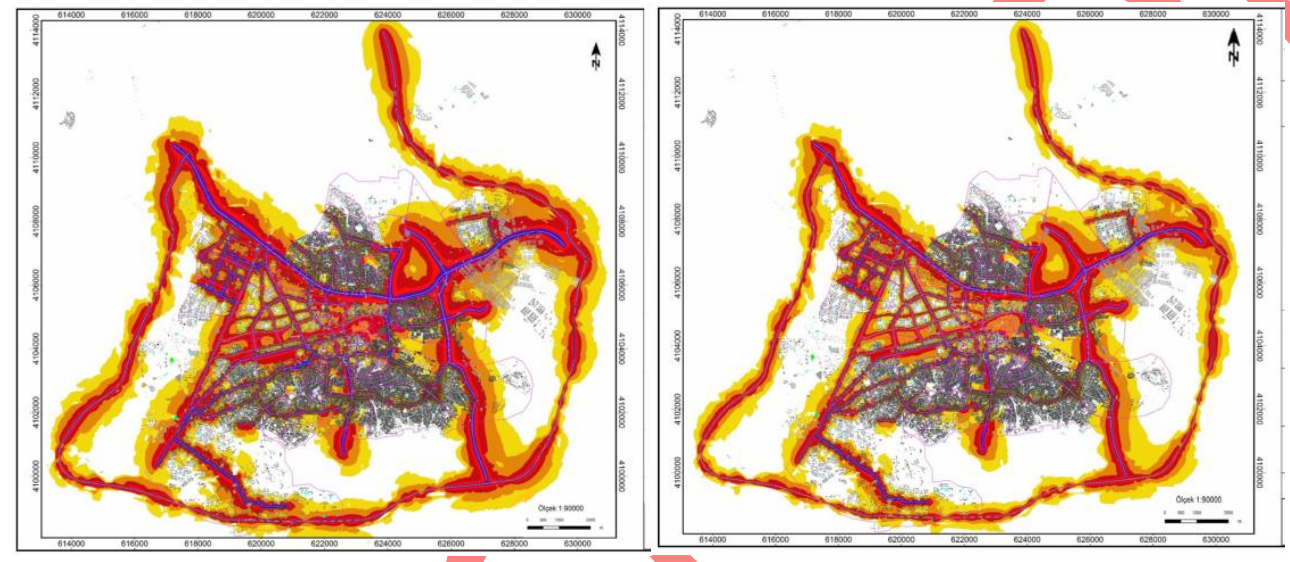

Şekil 2: Şahinbey ve Şehitkâmil ilçeleri karayolu stratejik gürültü haritası $5 d B(A)$ kontur aralıkları ile hazırlanmış Lgag (solda) ve Lgündüz (sağda)

Akşam ölçülen gürülttü değeri ( $\left.\mathrm{L}_{\text {akşam}}\right)$ ve gece ölçülen gürültü değeri $\left(\mathrm{L}_{\text {gece }}\right)$ cinsinden etkilenme analizi hesaplama sonuçları Tablo 5'te verilmektedir. 5 dB(A) kontur aralıkları ile hazırlanmış $\mathrm{L}_{\text {aksam }}$ ve $\mathrm{L}_{\text {gece }}$ Karayolu Stratejik Gürültü Haritası Şekil 3'de verilmiştir.

Tablo 5: Şahinbey ve Şehitkâmil ilçeleri (merkez) karayolu gürültüsü etkilenme analizi hesaplama sonuçları, Lakşam ve Lgece

\begin{tabular}{|l|c|c|c|c|c|c|c|c|c|c|}
\hline & \multicolumn{9}{|c|}{ Laksam } & \multicolumn{5}{c|}{ Lgece } \\
\hline $\begin{array}{l}\text { Gürülttï } \\
\text { Düzeyi } \\
(\mathbf{d B}(\mathbf{A}))\end{array}$ & $\begin{array}{c}\text { Alan } \\
\left(\mathbf{k m}^{2}\right)\end{array}$ & Konut & $\begin{array}{c}\text { Konut } \\
\text { Sakini }\end{array}$ & Okul & Hastane & $\begin{array}{c}\text { Alan } \\
\left.\mathbf{( k m}^{2}\right)\end{array}$ & Konut & $\begin{array}{c}\text { Konut } \\
\text { Sakini }\end{array}$ & Okul & Hastane \\
\hline $\mathbf{5 0 - 5 4}$ & 29,4 & 43.800 & 169.500 & 95 & 24 & 24 & 24.400 & 107.100 & 68 & 16 \\
\hline $\mathbf{5 5 - 5 9}$ & 19,7 & 24.200 & 105.800 & 66 & 13 & 13,6 & 13.900 & 65.900 & 46 & 26 \\
\hline $\mathbf{6 0 - 6 4}$ & 10,9 & 14.700 & 75.000 & 44 & 22 & 7,2 & 9.700 & 51.400 & 36 & 15 \\
\hline $\mathbf{6 5 - 6 9}$ & 6,2 & 9.900 & 47.000 & 40 & 15 & 4,8 & 6.500 & 28.700 & 21 & 9 \\
\hline $\mathbf{7 0 - 7 4}$ & 4,5 & 6.600 & 30.200 & 22 & 12 & 2,3 & 3.000 & 11.700 & 0 & 2 \\
\hline$>\mathbf{7 5}$ & 2,8 & 5.300 & 20.300 & 3 & 3 & 0,5 & 700 & 1.900 & 0 & 0 \\
\hline
\end{tabular}



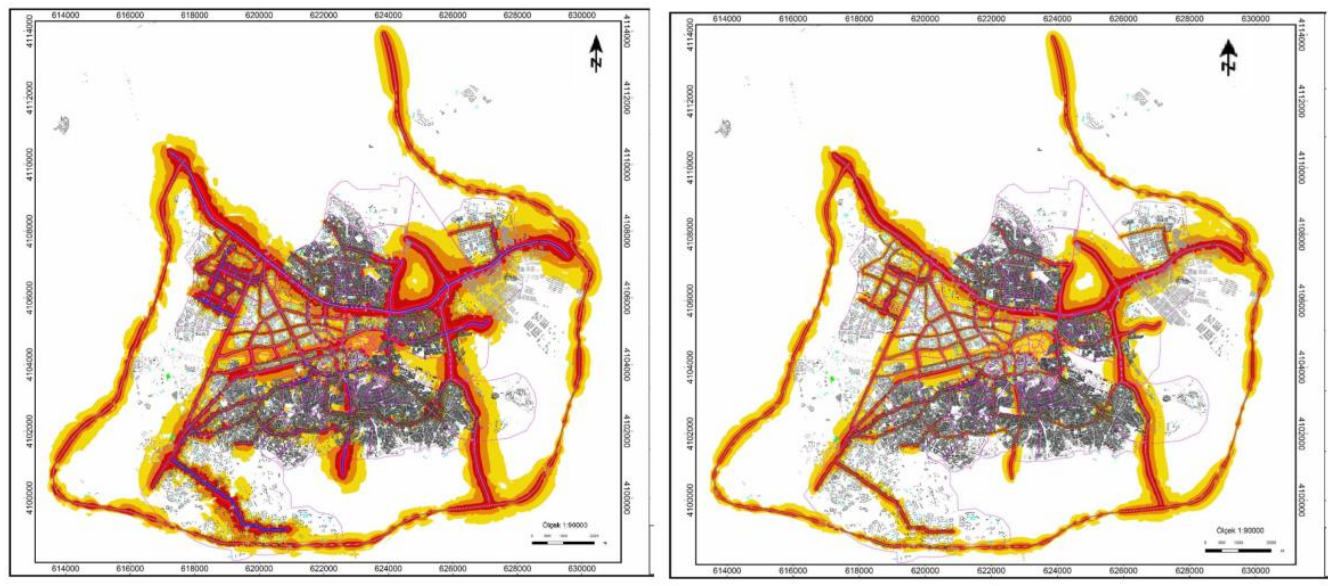

Şekil 3: Şahinbey ve Şehitkâmil ilçeleri karayolu stratejik gürültü haritası $5 d B(A)$ kontur aralıkları ile hazırlanmış Lakşam (solda) ve Lgece (sağda)

\subsection{Yüksek Seviyelerdeki Gürültüye Maruz Kalan Nüfusun Belirlenmesi}

Belirtilen indikatörlere göre stratejik gürültü haritaları hazırlandıktan sonra $\mathrm{L}_{\text {gag }}$ değerinin ve $\mathrm{L}_{\text {gece }}$ değerinin $>55$, $>65$ ve $>75 \mathrm{~dB}(\mathrm{~A})$ olduğu gürültü alanlarında yaşayan insan sayısının saptanması gerekmektedir. Bu kapsamda, karayollarından

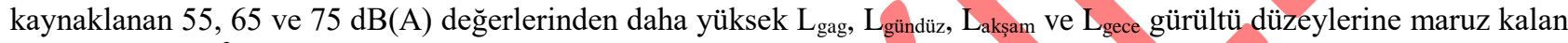
toplam alan $\left(\mathrm{km}^{2}\right)$ ile tahmini toplam konut sayısı ve bu alanlarda yaşayan tahmini toplam sakin sayısı hesaplanmıştır.

Modelleme sonucunda gürültü sınırlarına göre elde edilen $L_{\text {gag }}$ ve Lgündüz değerine bağlı sonuçlar Tablo 6'da verilmektedir. $\mathrm{L}_{\text {gag }}$ ve $\mathrm{L}_{\text {gündüz }}$ için Karayolu Stratejik Gürültü Haritası ve $>55,>65$ ve >75 dB(A) gürültü düzeyi değerlerine maruz kalan alanlar Şekil 4'de verilmektedir.

Tablo 6: Şahinbey ve Şehitkâmil ilçelerinde (merkez) gürültü sınırlarına göre karayolu kaynaklı Lgag ve Lgündüz değerinden

\begin{tabular}{|l|c|c|c|c|c|c|c|c|c|c|}
\hline & \multicolumn{3}{|c|}{ Lgündüz } \\
\hline $\begin{array}{l}\text { Gürültü } \\
\text { Düzeyi } \\
\mathbf{d B}(\mathbf{A})\end{array}$ & $\begin{array}{c}\text { Alan } \\
\left(\mathbf{k m}^{\mathbf{2}}\right)\end{array}$ & Konut & $\begin{array}{c}\text { Konut } \\
\text { Sakini }\end{array}$ & Okul & Hastane & $\begin{array}{c}\text { Alan } \\
\left(\mathbf{k m}^{2}\right)\end{array}$ & Konut & $\begin{array}{c}\text { Konut } \\
\text { Sakini }\end{array}$ & Okul & Hastane \\
\hline$>\mathbf{5 5}$ & 70,3 & 87700 & 386600 & 244 & 86 & 53,7 & 68.400 & 311.100 & 197 & 73 \\
\hline$>\mathbf{6 5}$ & 22,4 & 30700 & 146100 & 92 & 47 & 16,8 & 25.300 & 120.400 & 72 & 34 \\
\hline$>75$ & 6,4 & 9200 & 38000 & 11 & 10 & 4,8 & 7.000 & 28.000 & 6 & 5 \\
\hline
\end{tabular}
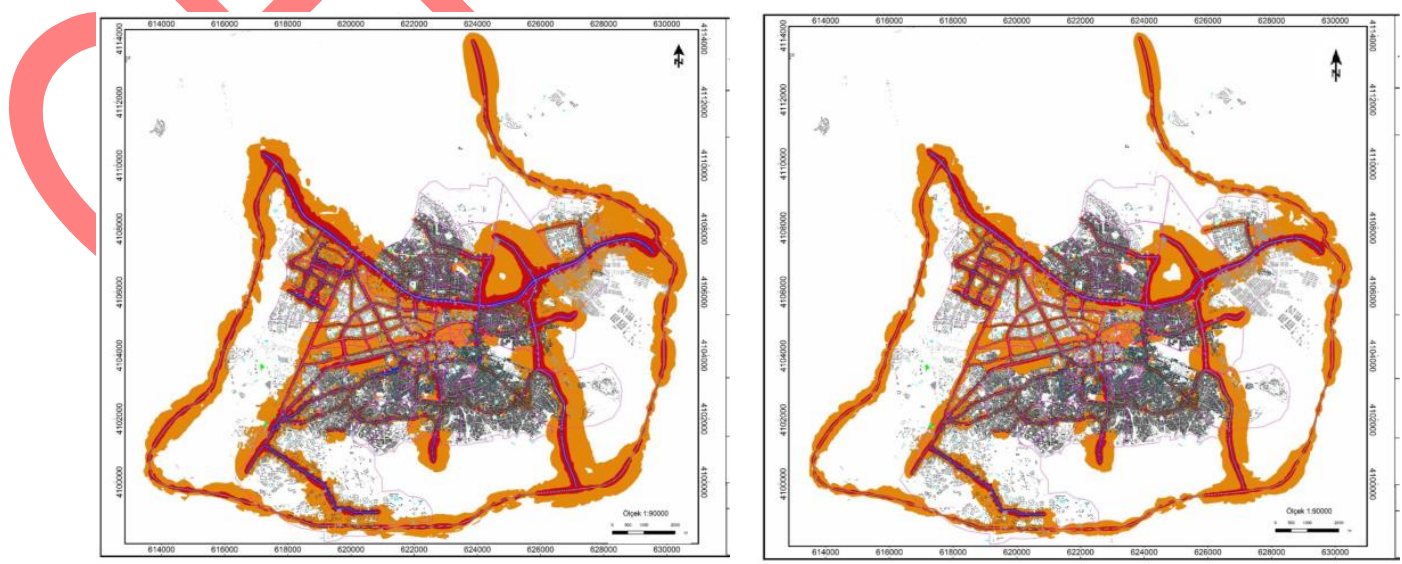

Şekil 4: Şahinbey ve Şehitkâmil ilçeleri karayolu stratejik gürültü haritası >55, >65, >75db(A) düzeylerine maruz kalan alanlar, $5 \mathrm{~dB}(A)$ kontur aralıkları ile hazırlanmış $L_{\text {gag }}$ (solda) ve Lgündüz (sağda) 
Hesaplanan $\mathrm{L}_{\mathrm{akşam}}$ ve $\mathrm{L}_{\text {gece }}$ değerlerine maruziyet ile ilgili sonuçlar Tablo 7'de verilmektedir. Lakşam ve Lgece için Karayolu Stratejik Gürültü Haritası ve $>55,>65$ ve $>75 \mathrm{~dB}(\mathrm{~A})$ gürültü düzeyi değerlerine maruz kalan alanlar Şekil 5 'te verilmektedir.

Tablo 7: Şahinbey ve Şehitkâmil Illçelerinde (Merkez) Gürültü sınırlarına göre karayolu kaynaklı Lakşam ve Lgece değerinden etkilenme

\begin{tabular}{|l|c|c|c|c|c|c|c|c|c|c|}
\hline & \multicolumn{5}{|c|}{ Laksam } & \multicolumn{5}{c|}{ Lece } \\
\hline $\begin{array}{l}\text { Gürülttï } \\
\text { Düzeyi } \\
(\mathbf{d B}(\mathbf{A}))\end{array}$ & $\begin{array}{c}\text { Alan } \\
\left(\mathrm{km}^{2}\right)\end{array}$ & Konut & $\begin{array}{l}\text { Konut } \\
\text { Sakini }\end{array}$ & Okul & Hastane & $\begin{array}{c}\text { Alan } \\
\left(\mathbf{k m}^{2}\right)\end{array}$ & Konut & $\begin{array}{c}\text { Konut } \\
\text { Sakini }\end{array}$ & Okul & Hastane \\
\hline$>\mathbf{5 5}$ & 44,1 & 60600 & 278200 & 175 & 65 & 28,4 & 33.700 & 159.600 & 103 & 52 \\
\hline$>\mathbf{6 5}$ & 13,5 & 21800 & 97400 & 65 & 30 & 7,6 & 10.100 & 42.300 & 21 & 11 \\
\hline$>\mathbf{7 5}$ & 2,8 & 5300 & 20300 & 3 & 3 & 0,5 & 700 & 1.900 & 0 & 0 \\
\hline
\end{tabular}

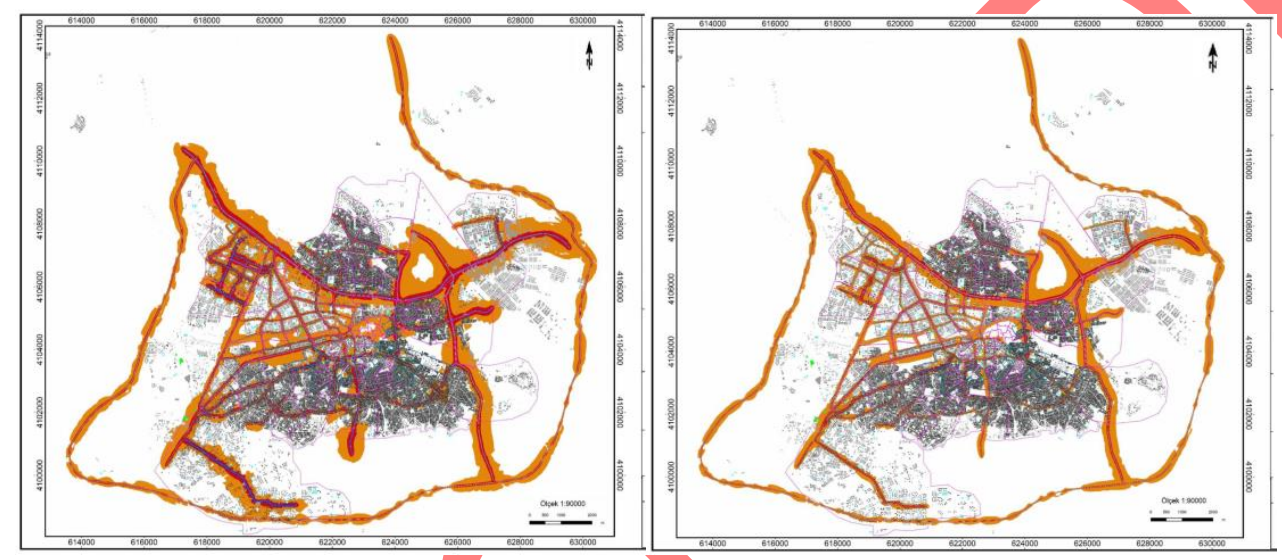

Şekil 5: Şahinbey ve Şehitkâmil ilçeleri karayolu stratejik gürültü haritası >55, >65, >75 db(A) düzeylerine maruz kalan alanlar, $5 \mathrm{~dB}(\mathrm{~A})$ kontur aralıkları ile hazırlanmış Lakşam (solda) ve Lgece (sağda)

\subsection{Gürültü Sınır Değerlerin Aşııdığı Alanlar}

Karayolundan çevreye yayılan gürültü seviyesi ve gürültünün önlenmesine ilişkin sınır değerler Tablo 8'de belirtilmişstir. Karayollarından kaynaklanan çevresel gürültü seviyesi Tablo 8'deki sınır değerleri aşmaması gerekmektedir.

Tablo 8: Karayolu çevresel gürültü sınır değerleri (URL-1 2010)

\begin{tabular}{|c|c|c|c|c|c|c|}
\hline & \multicolumn{3}{|c|}{$\begin{array}{l}\text { Planlanan/Yenilenmiş/ } \\
\text { Onarılmış Yollar }\end{array}$} & \multicolumn{3}{|c|}{ Mevcut Yollar } \\
\hline & $\mathbf{L}_{\text {gündüz }}$ & Lakşam & Lgece & $\mathbf{L}_{\text {gündüz }}$ & Lakşam & Lgece \\
\hline $\begin{array}{l}\text { Gürülttüye hassas kullanımlardan eğitim, kültür ve sağlık } \\
\text { alanları ile yazlık ve kamp yerlerinin ağırlıklı olduğu alanlar }\end{array}$ & 60 & 55 & 50 & 65 & 60 & 55 \\
\hline $\begin{array}{l}\text { Ticari yapılar ile gürülttüye hassas kullanımların birlikte } \\
\text { bulunduğu alanlardan konutların yoğun olarak bulunduğu } \\
\text { alanlar }\end{array}$ & 63 & 58 & 53 & 68 & 63 & 58 \\
\hline $\begin{array}{l}\text { Ticari yapılar ile gürülttüye hassas kullanımların birlikte } \\
\text { bulunduğu alanlardan işyerlerinin yoğun olarak bulunduğu } \\
\text { alanlar }\end{array}$ & 65 & 60 & 55 & 70 & 65 & 60 \\
\hline Endüstriyel alanlar & 67 & 62 & 57 & 72 & 67 & 62 \\
\hline
\end{tabular}

Çalışma alanı, Tablo 8'de tanımlanan "Ticari yapılar ile gürültüye hassas kullanımların birlikte bulunduğu alanlardan konutların yoğun olarak bulunduğu alanlar” olarak kabul edilmiştir. Projedeki karayollarının etki alanındaki değerlendirmeler için, aynı tabloda karayollarına yönelik verilen sınır değerler kullanılmıştır. 
Yapılan değerlendirmeler sonucunda proje çalışma alanı kapsamında sınır değerlerin aşıldığı alanlardaki konut sayısı, konut sakini sayısı, okul sayısı ve hastane sayısı belirlenmiştir. Çalışma alanında maruziyet aşımını gösteren gece, gündüz ve akşam için verilen sınır değer aşım hesaplama sonuçları Tablo 9'da verilmektedir. Bu verilere göre belirlenen nüfus yüzdelik değerleri de Şekil 6'da verilmektedir.

Tablo 9: Şahinbey ve Şehitkâmil ilçeleri (merkez) karayolu gürültüsü sınır değer aşım hesapları

\begin{tabular}{|l|c|c|c|c|}
\hline Sınır Değerler dB(A) & Konut & Konut Sakini & Okul & Hastane \\
\hline$<\mathbf{6 8}$ (Lgündüz) & 18.700 & 83.800 & 47 & 26 \\
\hline$<\mathbf{6 3}$ (Lakşam) & 26.900 & 127.400 & 80 & 34 \\
\hline$<\mathbf{5 8}$ (Lgece) & 24.600 & 117.100 & 74 & 35 \\
\hline
\end{tabular}

Gürültü haritaları sonuçlarına göre Gaziantep nüfusunun \% 7,5'i geceleri (Lgece) $58 \mathrm{~dB}(\mathrm{~A})$ ve üzeri, \% 8,2'si akşamları ( $\left.\mathrm{L}_{\text {akşam }}\right) 63 \mathrm{~dB}(\mathrm{~A})$ ve üzeri ve \% 5,4'ü gündüzleri ( $\mathrm{L}_{\text {gündüz }}$ ) $68 \mathrm{~dB}(\mathrm{~A})$ ve üzeri karayolu kaynaklı gürültü seviyelerine maruz kalmaktadır. Yine aynı şekilde, toplam çalışma alanında bulunan 201 okul ve 95 hastane belirlenen kritik seviyelerin üzerinde karayolu kaynaklı gürültü seviyelerine maruz kalmaktadır.

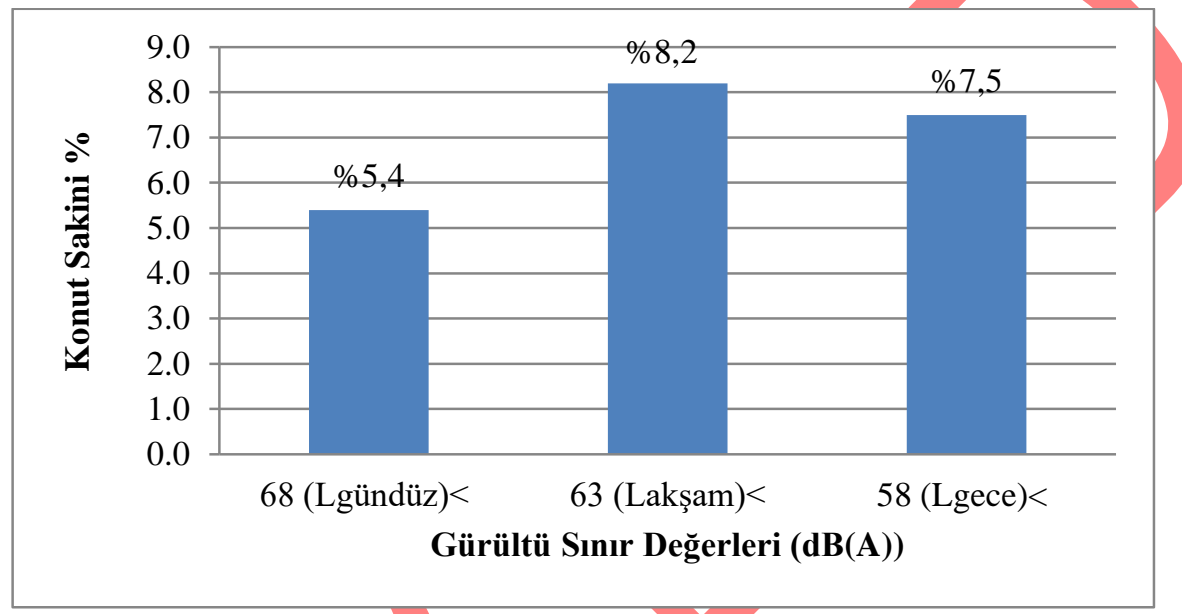

Şekil 6: Gece, akşam ve gündüz verilerine göre belirlenen sınır değerlere maruz kalan nüfus yüzdelik oranları.

Hazırlanan gürültü haritası sonuçlarına göre belirlenen sınır değerlerin üzerinde gürültüye maruz kalan bölgelerde "Gürültü Eylem Planlarının" hazırlanması gerekmektedir. Eylem planları kapsamında gürültü düzeylerinin hangi seviyelere indirileceği ve uygulanacak metot aktif ve pasif eylem planları olarak iki şekilde belirlenmektedir. Pasif eylem planlarında bina cephelerine gelen gürültü düzeyi bilinmesi durumunda, sınırların aşıldığı binalarda akustik yalıtım yapılmaktadır. Aktif eylem planlarında ise gürültünün arazi üzerinde nasıl yayıldığı ve bina cephelerine gelen gürültü seviyeleri bilinmekte ve alıcı ile gürültü kaynağı arasına çeşitli hesaplamalara göre gürültü bariyerleri yerleştirilmesi gerekmektedir. Günümüzde kullanılan gürültü bariyerleri, emici ve yansıtıcı paneller olarak 2 grupta toplanabilir. Bariyerler; ahşap (çit, kalas, kontrplak levhalar), beton (takviyeli, öngermeli), duvar (taş, beton), çelik, alüminyum, şeffaf (akrilik, sertleştirilmiş cam) veya toprak şevler ve bitki örtüsü olarak tasarlanabilmektedirler. Etkili gürültü bariyerleri genellikle trafik gürültü seviyelerini 5 ila $12 \mathrm{~dB}(\mathrm{~A})$ kadar azaltır. Gürültü bariyerlerinin fiziki alan kısıtlamalarından dolayı kullanılamayacağı bölgelerde ise trafik talep yönetimi çözümleri ile gürültü seviyeleri düşürülmelidir. Bu çalışmanın sonuçlarına göre hazırlanacak olan bir “Gürültü Eylem Planı”nda gerekli aktiviteler, boyutlandırmalar ve hesaplamalar yapilmalidir.

\section{Sonuçlar ve Değerlendirmeler}

Çevresel gürültü ile ilgili sorunların belirlenmesi ve gerekli kontrol tedbirlerinin alınabilmesi için stratejik gürültü haritalarının hazırlanması büyük önem taşımaktadır. Bu çalışmada, Gaziantep kent içi karayolu trafiğinden kaynaklanan stratejik gürültü haritaları değerlendirilmiştir. Proje çalışma alanında yer alan karayolu stratejik gürültü haritası

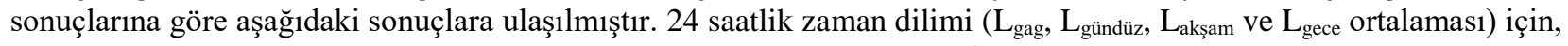

- $\quad 75 \mathrm{~dB}(\mathrm{~A})$ ve üzeri gürültü düzeyinden etkilenen yaklaşık $6,4 \mathrm{~km}^{2}$ lik bir alanda 9.200 konut, 11 okul, 10 hastane ve 38.000 konut sakini,

- $\quad 65 \mathrm{~dB}(\mathrm{~A})$ ve üzeri gürültü düzeyinden etkilenen yaklaşık 22,4 km²'lik bir alanda 30.700 konut, 92 okul, 47 hastane ve 146.100 konut sakini, 
- $\quad 55 \mathrm{~dB}(\mathrm{~A})$ ve üzeri gürültü düzeyinden etkilenen yaklaşık 70,3 km²'lik bir alanda 87.700 konut, 244 okul, 86 hastane ve 386.600 konut sakini bulunmaktadir.

Gece zaman dilimi (Lgece) için;

- $\quad 75 \mathrm{~dB}(\mathrm{~A})$ ve üzeri gürültü düzeyinden etkilenen yaklaşık $0,5 \mathrm{~km}^{2 \prime}$ bir alanda 700 konut ve 1.900 konut sakini,

- $65 \mathrm{~dB}(\mathrm{~A})$ ve üzeri gürültü düzeyinden etkilenen 7,6 km²'lik bir alanda 10.100 konut, 21 okul, 11 hastane ve 42.300 konut sakini,

- $\quad 55 \mathrm{~dB}(\mathrm{~A})$ ve üzeri gürültü düzeyinden etkilenen $28,4 \mathrm{~km}^{2}$ lik bir alanda 33.700 konut, 103 okul, 52 hastane ve 159.600 konut sakini bulunmaktadır.

Bu sonuçlar ve ÇGDYY sınır değerlerine göre Gaziantep nüfusunun \%5,4'ü gündüzleri $68 \mathrm{~dB}(\mathrm{~A})$ ve üzeri; \%8,2'si akşamları $63 \mathrm{~dB}(\mathrm{~A})$ ve üzeri ve \%7,5'i geceleri $58 \mathrm{~dB}(\mathrm{~A})$ ve üzeri; karayolu kaynaklı gürültü seviyelerine maruz kalmaktadır. Toplam çalışma alanında bulunan 201 okul ve 95 hastane belirlenen kritik seviyelerin üzerinde karayolu kaynaklı gürültü seviyelerine maruz kalmaktadır. Bu seviyeler Dünya Sağlık Örgütü’nün belirlediği 24 saat için $40 \mathrm{~dB}$, gece için $55 \mathrm{~dB}$ değerlerinin ve Amerikan Çevre Ajansının belirlediği $70 \mathrm{~dB}$ işitme kaybı, $45 \mathrm{~dB}$ hassas alanlar, $55 \mathrm{~dB}$ dış mekân sınır değerlerinin de üzerinde kalmaktadır. Bu durumda, bahsi geçen nüfus oranlarında işitme kaybı, fizyolojik tepkiler olarak; stres, kardiyovasküler etkiler, kalp krizi, yüksek tansiyon, inme veya felç, ülser, sindirim sistemi sorunları ve fetüs üzerindeki etkiler, psikolojik tepkiler olarak; anti sosyal davranış, yardım etme isteğinde azalma gibi sağlık sorunları ortaya çıkabilecektir.

Türkiye'de yapılan önceki çalışmalarda elde edilen karayolu kaynaklı en yükssek gürültü değerinin 109 dB(A) ile Avanos'ta olduğu ve bu değeri $90 \mathrm{~dB}(\mathrm{~A})$ ile Afyonkarahisar'ın takip ettiği görülmektedir. Çalışmalar arasında ölçülen en düşük değer ise $68 \mathrm{~dB}(\mathrm{~A})$ ile Giresun'da olmuştur. Büyükşehir Belediyelerinin merkez ilçelerini kapsayan çalışmalara bakıldığında ise Gaziantep'e benzer şekilde Samsun, İzmit ve Konya'da birbirine yakın olarak 60-70 dB(A) değerleri elde edilmiştir. Trafikten kaynaklı $55 \mathrm{~dB}(\mathrm{~A})$ Lgece değerini aşan gürültüye maruz kalan Gaziantep’teki \%7,5 nüfus oranının Konya'da elde edilen \%10-15 değerinden düşük olduğu görülmüştür.

Bu konuda yapılacak gelecek çalışmalar için en önemli konu maruziyet düzeylerine göre gerekli gürültü bariyerleri, akustik yol kaplama türleri ve trafik hacmini düzenleyici trafik talep yönetimi projeleri uygulamaları gibi aktivitelerin belirleneceği eylem planlarının hazırlanmasıdır. İlgili uzmanların ve sorumlu kuruluşların bir araya gelerek bu eylem planlarını hazırlamaları ve toplum sağlığını tehdit eden gürültü maruziyetlerini ortadan kaldıracak şekilde projeler oluşturmaları gerekmektedir.

\section{Teşekkür}

Bu çalışmada; Gaziantep Büyükşehir Belediyesi'nde 2016'da tamamlanan "Yerleşim Alanlarının Stratejik Gürültü Haritalarının Hazırlanması Projesi”nin sonuç raporundan yararlanılmıştır. Çalışmaya katkılarından dolayı Çevre ve Şehircilik Bakanlığı'na, TÜBİTAK MAM’a ve Gaziantep Büyükşehir Belediyesi’ne teşekkürlerimizi sunarız.

\section{Kaynaklar}

Bayraktar Ş. (2006). İzmit kentmerkezinin gürültü kirliliği, Yüksek Lisans Tezi, Kocaeli Üniversitesi, Fen Bilimleri Enstitüsü, Kocaeli. Besnard F., Hamet J.F, Lelong J., Le Duc E., Guizard V., Fürst N., Doisy S., Dutilleux G., (2011), Road noise prediction 1 - Calculating sound emissions from road traffic, Republic of France, Setra Editions, France, 125ss.

Bodin T., Albin M., Ardo J., Stroh E., Ostergren P.O., Bjork J., (2009), Road traffic noise and hypertension: results from a crosssectional public health survey in southern Sweden, Environ. Health 8, 38, doi: 10.1186/1476-069X-8-38.

Borelli D., Repetto S., Schenone C., (2014), Noise mapping of the Flyover Highway in Genoa: comparison of different methods, Noise Mapping, 1(1), 59-73.

Çivi A., Akgündüz E., Kalaycı K., İnan Ç., Sarıca E., Toru, E., (2009), CORINE (Coordination of Information on the Environment) Projesi, TMMOB Coğrafi Bilgi Sistemleri Kongresi, 02- 06 Kasım, İzmir.

ÇŞB, (2018), Çevresel gürültü eylem planı 2009-2020, T.C. Çevre ve Şehircilik Bakanlığ1, http://www.cygm.gov.tr/CYGM/Files/ EylemPlan/Cevresel_\%20Gurultu_\%20Eylem_Plani.pdf. [Erişim 30 Mart 2020].

Dalkılıç E., Dursun Ş., (2019), Konya Gürültü Kirliliği ve Eylem Planlarının Yorumlanması, Düzce Üniversitesi Bilim ve Teknoloji Dergisi, 7(2), $38-51$.

Erdoğan S., Doğan M., Yılmaz İ., Güllü M., Baybura T., Ulu M., Sise Ö., (2007), Afyonkarahisar il merkezi karayolu trafik gürültü haritasinin hazırlanması, Afyon Kocatepe Üniversitesi Fen ve Mühendislik Bilimleri Dergisi, 7(2), 151-164.

EC, (2020), Health effects of noise, European Commission, https://ec.europa.eu/environment/noise/health_effects_en.htm, [Erişim 7 Nisan 2020].

EC, (2007), Position Paper - Good Practice Guide for Strategic Noise Mapping and the Production of Associated Data on Noise Exposure, Version 2, European Commission Working Group Assessment of Exposure to Noise (WG-AEN), 129ss.

EPA, (1974), EPA Identifies Noise Levels Affecting Health and Welfare, https://archive.epa.gov/epa/aboutepa/epa-identifies-noiselevels-affecting-health-and-welfare.html, [Erişim 12 Kasim 2020].

EPA, (1981), Noise Effects Handbook, https://www.nonoise.org/library/handbook/handbook.htm, [Erişim 12 Kasım 2020]. 
EU, (2002), The Environmental Noise Directive, European Union, 25 June 2002, https://ec.europa.eu/environment/noise/ directive_en.htm. [Erişim 30 Mart 2020].

Gulliver J., Morley D., Vienneau D., Fabbri F., Bell M., Goodman P., Fecht D., (2015), Development of an open-source road traffic noise model for exposure assessment, Environ. Model Softw., 74, 183-193.

Italo C., Montalvão G., Bertoli S.R., Zannin P.H.T., (2011), Influence of urban shapes on environmental noise: a case study in Aracaju-Brazil, Science of The Total Environment, 412-413, $66-76$.

Johnson D.R., Saunders E.G., (1968), The Evaluation of Noise from Freely Flowing Road Traffic, Journal of Sound and Vibration, 7(2), 287-309.

Kalıpcı E., (2017), Avanos ilçe merkezinde trafik kaynaklı gürültü kirliliğinin mekânsal analizi, Nevşehir Bilim ve Teknoloji Dergisi, 6(1), 20-29.

Kalıpc1 E., Arslan F., (2007), Determination of noise pollution knowledge in the sport centers of Konya city, Journal of International Environmental Application \& Science, 2(3\&4), 63-69.

Kalıpc E., Dursun Ş., (2009), Presentation of Giresun city traffic noise pollution map via geographical information system, Journal of Applied Sciences, 9(3), 479-487.

Karantonis P., Gowen T., Simon M., (2010), Further Comparison of Traffic Noise Predictions Using the Cadna and Sound PLAN Noise Prediction Models, Proceedings of 20th International Congress on Acoustics, ICA 2010, 23-27 August, Sydney, Australia.

Khan J., Ketzel M., Kakosimos K., Sørensen M., Jensen S.S., (2018), Road traffic air and noise pollution exposure assessment - a review of tools and techniques, Sci. Total Environ., 634, 661-676.

Kuehnel N., Moeckel R., (2020), Impact of simulation-based traffic noise on rent prices, Transportation Research Part D: Transport and Environment, 78, 102191, doi: 10.1016/j.trd.2019.11.020.

Kurra S., (2009), Çevre Gürültüsü ve Yönetimi, Bahçeşehir Üniversitesi Yayınları, İstanbul, 298ss.

Lee E.Y., Jerrett M., Ross Z., Coogan P.F., Seto E.Y.W., (2014), Assessment of traffic-related noise in three cities in the United States, Environ. Res., 132, 182-189.

Nelson P., (1987), Transportation Noise Reference Book, Butterworth-Heinemann, Butterworth, 520ss.

Nelson P., Piner R.J., (1977), Classifying road vehicles for the prediction of road traffic noise, Transport and Road Research Laboratory, Department of Environment, LR 752.

Öden M.K., Bilgin İ., (2019), Sarayönü ilçe merkezinde trafik kaynaklı gürültü kirliliğinin araştırtması, Çukurova Üniversitesi Mühendislik-Mimarlık Fakültesi Dergisi, 34(1), 103-114.

Öner İ., Sesli F.A., (2018), Imar planlarının trafik gürültü değerlerinin etkisi açısından incelenmesi, Samsun Atakum bölgesi örneği, Kent Akademisi, 11(3), 390-404.

Özdemir C., Kalıpcı E., (2011), Kentlerde yaşanan trafik kaynaklı gürültü kirliliği ve çözüm önerileri, İçişleri Bakanlığı Emniyet Genel Müdürlüğ̈̈, Karayolu Trafik Güvenliği Sempozyum ve Fuarı, 10-12 May1s, Ankara, ss.22.

Özdemir C., Kalıpcı E., Öden M.K., Özdöner A., Şahinkaya S., (2012), Konya il merkezinde trafik kaynaklı gürültü kirliliği ölçümü ve insan sağlı̆̆ına etkileri, 21.Ulusal Biyoloji Kongresi, Ege Üniversitesi, 3-7 Eylül, İzmir, ss.851.

Seidler A., Hegewald J., Seidler A.L., Schubert M., Wagner M., Dröge P., Haufe E., Schmitt J., Swart E., Zeeb H., (2017), Association between aircraft, road and railway traffic noise and depression in a large case-control study based on secondary data, Environmental Research, 152, 263-271.

Seidler A., Wagner M., Schubert M., Dröge P., Hegewald J., (2016), Aircraft, road and railway traffic noise as risk factors for heart failure and hypertensive heart disease - A case-control study based on secondary data, International Journal of Hygiene and Environmental Health, 219, 749-758.

Sillelioğlu F., (2004), Balıkesir ilinde gürültü haritalarının oluşturulması üzerine bir araştırma, Yüksek Lisans Tezi, Balıkesir Üniversitesi Fen Bilimleri Enstitüsü, Balıkesir.

Sorensen M., Andersen Z.J., Nordsborg R.B., Becker T., Tjonneland A., Overvad K., Raaschou-Nielsen O., (2013), Long-term exposure to road traffic noise and incident diabetes:acohort study, Environ. Health Perspect., 121 (2), $217-222$.

Sorensen M., Andersen Z.J., Nordsborg R.B., Jensen S.S., Lillelund K.G., Beelen R., Raaschou-Nielsen O., (2012), Road traffic noise and incident myocardial infarction: a prospective cohort study, PLoSOne, 7(6):e39283, doi: 10.1371/journal.pone.0039283.

Sorensen M., Hjortebjerg D., Eriksen K.T., Ketzel M., Tjonneland A., Overvad K., Raaschou-Nielsen O., (2015), Exposure to longterm air pollution and road traffic noise in relation to cholesterol: a cross-sectional study, Environ. Int., 85, $238-243$.

Sorensen M., Luhdorf P., Ketzel M., Andersen Z.J., Tjonneland A., Overvad K., Raaschou-Nielsen O., (2014). Combined effects of road traffic noise and ambient air pollution in relation to risk for stroke? Environ. Res., 133, 49-55.

TRB, (2010), Highway Capacity Manual, Transportation Research Board, National Research Council, New York, USA.

TS 6407, (2013), Şehir içi ulaşım hesaplamalarında kullanılan araç tiplerine göre otomobil eşdeğeri katsayıları, https://intweb.tse.org.tr/Standard/Standard/Standard.aspx?081118051115108051104119110104055047105102120088111043113 104073086075079047106069087102066090067, [Erişim 30 Mart 2020].

TÜBİTAK-MAM (2016), Yerleşim alanlarının stratejik gürültü haritalarının hazırlanması projesi raporu, Gaziantep Büyükşehir Belediyesi, Gaziantep, 255ss.

URL-1, (2010), Çevresel Gürültünün Değerlendirilmesi ve Yönetimi Yönetmeliği, Resmî Gazete Tarihi: 04.06.2010 Resmî Gazete Sayıs1: 27601, https://www.mevzuat.gov.tr/Metin.Aspx?MevzuatKod=7.5.14012\&MevzuatIliski=0. [Erişim 30 Mart 2020].

URL-2, (2014), Mekânsal Planlar Yapım Yönetmeliği, Resmî Gazete Tarihi: 14.06.2014 Resmî Gazete Sayısı: 29030, https://www.resmigazete.gov.tr/eskiler/2014/06/20140614-2.htm. [Erişim 11 Kasım 2020].

USDT (2010), Highway Traffic Noise: Analysis and Abatement Guidance, U.S. Department of Transportation-Federal Highway Administration, https://www.fhwa.dot.gov/environment/noise/regulations_and_guidance/analysis_and_abatement_guidance/ revguidance.pdf, [Erişim 30 Mart 2020].

Vogiatzis K., Remy N., (2014), Strategic Noise Mapping of Herakleion: The Aircraft Noise Impact as a factor of the Int. Airport relocation. Noise Mapping 1(1). https://doi.org/10.2478/noise-2014-0003.

Vos P., Beuving M., Verheijen E., (2005), Project Harmonoise, Harmonised Accurate and Reliable Methods for the EU Directive on the Assessment and Management of Environmental Noise - Final Technical Report, http://doutoramento.schiu.com/referencias/ 
outras/Harmonised\%20Accurate\%20and\%20Reliable\%20Methods\%20for\%20the\%20EU\%20Directive.pdf, [Erişim 26 Şubat 2020].

WHO, (2020), Noise, https://www.euro.who.int/en/health-topics/environment-and-health/noise/noise, [Erişim 12.11.2020].

Zeeb H., Hegewald J., Schubert M., Wagner M., Seidler, A., (2017), Traffic noise and hypertension - results from a large case-control study, Environmental Research, 157, 110-117.

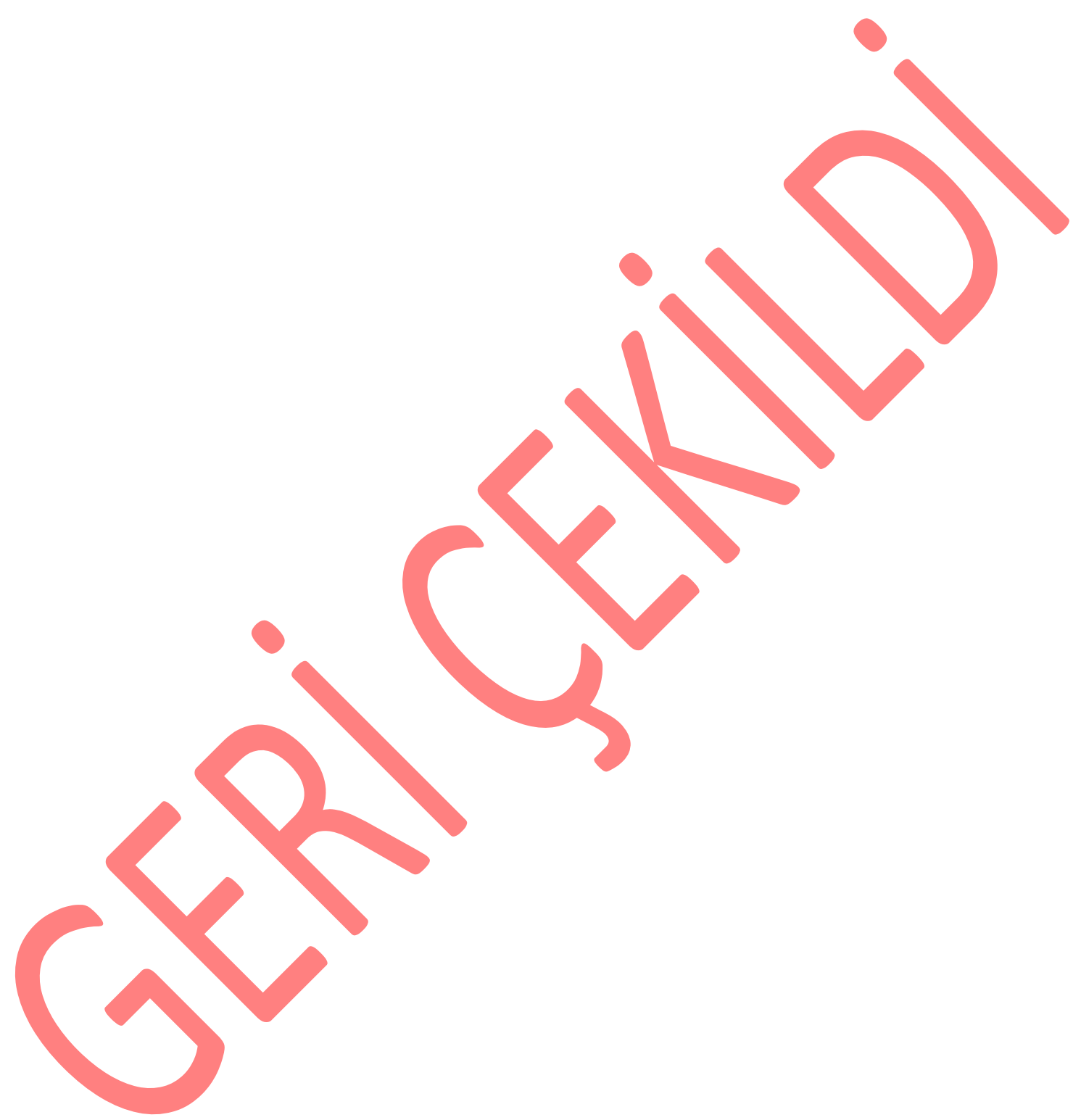

